\title{
Cascade Synthesis of L-Homoserine Catalyzed by Lyophilized Whole Cells Containing Transaminase and Aldolase Activities: The Mathematical Modeling Approach
}

\author{
Morana Česnik Katulić, Martina Sudar, Karel Hernández, Yuyin Qi, Simon J. Charnock, \\ Đurdica Vasić-Rački, Pere Clapés, and Zvjezdana Findrik Blažević*
}

Cite This: Ind. Eng. Chem. Res. 2021, 60, 13846-13858

Read Online

ABSTRACT: Aldolase and transaminase coexpressed in Escherichia coli cells and lyophilized (i.e., lyophilized whole-cell biocatalyst (LWCB)) were used as biocatalysts for the one-pot cascade synthesis of L-homoserine with substrate cycling. The kinetic analysis of enzymes within lyophilized cells was performed to evaluate the behavior of the system. The best result among the performed fed-batch reactor experiments achieved was $640.8 \mathrm{mM}\left(76.3 \mathrm{~g} \mathrm{~L}^{-1}\right)$ of L-homoserine with a volume productivity of $2.6 \mathrm{~g} \mathrm{~L}^{-1} \mathrm{~h}^{-1}$. This is comparable with the results of the same cascade synthesis using cell-free extracts (CFEs) and significantly better than the reports in the literature applying fermentation technology. The approach applied here can serve as guidance for the design of microbial cells with an optimal ratio of expressed enzymes that act as biocatalysts in the cascade, resulting in lower biocatalyst cost, no need for the addition of expensive coenzymes, and enhanced enzyme stability as compared with cell-free extracts.

\section{INTRODUCTION}

Biotechnological processes have the potential to produce specific products in high yields with low energy consumption and minimal waste generation. ${ }^{1-3}$ It is often the case that biocatalytic processes explored in the laboratory show favorable opportunities from the standpoint of green chemistry but also demonstrate limitations in terms of their economic potential. ${ }^{4}$ Therefore, to achieve the full potential benefits that biotechnology has to offer, processes must be optimized to reach satisfactory process metrics, i.e., reaction yield, product concentration, and biocatalyst yield, as emphasized in a recent review article on the industrial application of biocatalysis. ${ }^{5}$ These values depend on the industrial sector, e.g., higher values should be obtained for bulk chemicals than for the pharma sector. $^{6}$ In the early stages of process development, welldefined process metrics can drive the progress in the right direction. Thus, adequate tools must be used to speed up the development time and to decrease the resources needed for process optimization. ${ }^{7,8}$ Many bright examples in the recent literature illustrate the application of mathematical modeling in the development of biocatalytic processes, from those simpler $^{9-12}$ to significantly more complex, such as the cascade reactions. ${ }^{13-18}$ Advanced modeling techniques increase the rate of the development and industrialization of new biocatalytic processes. They enable the formation of mathematical relationships between the system variables, allowing the prediction of the reaction scenarios without the need of conducting experiments in the reactor. This saves time, money, and labor. ${ }^{19,20}$ To reach that stage of utilization, the mathematical model needs to be validated, i.e., to be applicable for exploration of the variable space. ${ }^{20}$ In our previous work, a model for the synthesis of L-homoserine in a complex one-pot cascade two-enzyme reaction system was developed and applied for process optimization and selection of the reactor mode. An L-homoserine concentration of $80.1 \mathrm{~g} \mathrm{~L}^{-1}$ was accomplished, yielding a volume productivity of $3.2 \mathrm{~g} \mathrm{~L}^{-1} \mathrm{~h}^{-1}$ in $25 \mathrm{~h}$. In this work, we aim to demonstrate the behavior of the same reaction system when both enzymes required for the catalysis are overexpressed in Escherichia coli cells, i.e., lyophilized whole-cell biocatalyst (LWCB). Such a cascade is classified as in vitro cascade according to the literature and its advantage is in the fact that the amount of each biocatalyst can be adjusted to reach maximum overall flux. ${ }^{21}$ The need to combine multienzymatic synthesis, kinetic modeling, and fine tuning of the expression system to reach required individual enzyme concentrations was emphasized in a work by Rios-Solis and coauthors. ${ }^{22}$ For wider implementation of cascades in the industry, it is necessary to optimize them with respect to

Received: June 17, 2021

Published: September 16, 2021 
product cost, product purity, concentration, catalyst stability, solvent tolerance, and catalyst recyclability. ${ }^{21}$ In a review article, Rudroff covers the challenges and hurdles that need to be overcome in whole-cell cascade biocatalysis, as well as strategies on how to increase the overall cascade productivity. ${ }^{23}$ Enzyme kinetics characterization and modeling are discussed within examples as one of the ways to accomplish this goal. $^{23}$ It is important to emphasize that combining different biocatalysts in one pot to perform the cascade reactions increases the efficiency of biocatalysis, which is considered a powerful tool in organic chemistry. ${ }^{24}$

L-Homoserine, synthesized in this work, is a noncanonical amino acid, a precursor of essential amino acids such as Lthreonine, L-methionine, and L-isoleucine. ${ }^{25-29}$ It is also a valuable building block for the synthesis of 3-hydroxypropionaldehyde and 1,3-propanediol ${ }^{30-33}$ and has potential applications as a fertilizer and feed additive. ${ }^{34,35}$ Several examples in the literature ${ }^{35-38}$ reported the metabolic engineering of microorganisms for the production of $\mathrm{L}$ homoserine. Metabolic engineering implies the use of growing cells as catalysts, which basically means that the biocatalyst is produced simultaneously as the reaction is carried out. ${ }^{39}$ The downside of this technology is the formation of an unwanted acetic acid as a byproduct during the fermentation in concentrations of ca. 5.2-6.9 $\mathrm{g} \mathrm{L}^{-1}, 35,37$ which shows a toxic effect toward E. coli at concentrations of $5 \mathrm{~g} \mathrm{~L}^{-1}$ and higher. ${ }^{40}$ This can lower the yield and productivity since the cells use the substrate for cell growth, as well as for synthesizing the target product. $^{39,41}$ Therefore, to overcome these problems, resting, lyophilized cells of $E$. coli containing a transaminase and an aldolase (LWCB) were investigated to produce L-homoserine using a one-pot two-enzyme cascade reaction system (Scheme $1)$. The first reaction is the aldol addition of pyruvate to

\section{Scheme 1. Reaction Scheme}

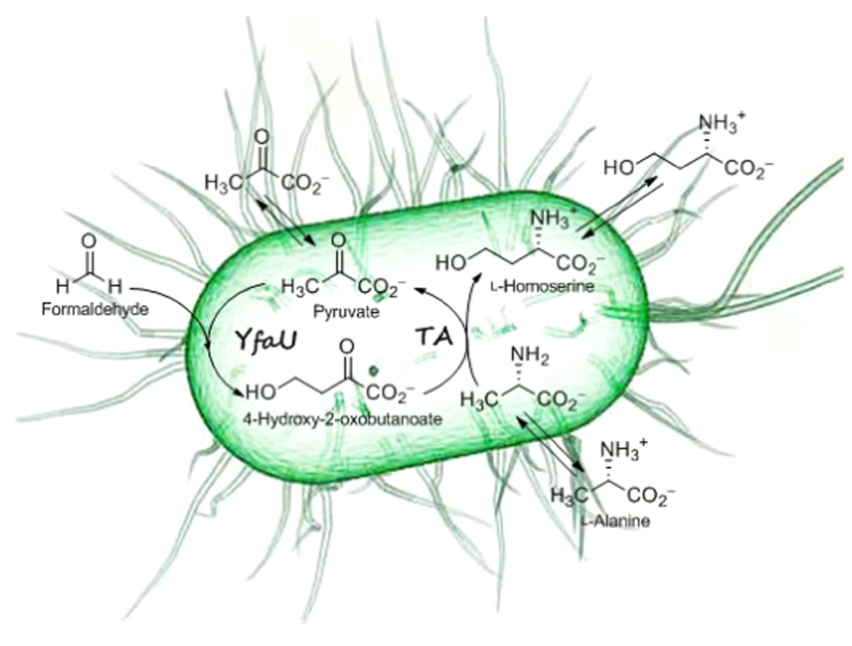

formaldehyde and the second one is the transamination, i.e., reductive amination, of the aldol adduct using L-alanine as the amino donor. This cascade reaction was investigated previously using purified enzymes ${ }^{18,42}$ and cell-free extracts (CFEs). ${ }^{18,42}$ In this paper, the aim was to simplify the system by avoiding the need for enzyme isolation and purification. Another objective was to investigate the performance of the reaction catalyzed by CFE compared with that using LWCB. The literature $^{13}$ shows that a mathematical model of a reaction catalyzed by free enzymes in vitro can be applied to understand the bottlenecks of the reaction catalyzed by enzymes in the living whole cells, as well. In this paper, we tested the hypothesis on an in vitro approach by evaluating the kinetics of LWCB and comparing the results with the previously reported ones with CFE. ${ }^{18,42}$ Furthermore, the model developed for the reaction with $\mathrm{CFE}$ can be used to determine the ratio of transaminase and aldolase activities for coexpression in LWCB necessary to achieve good process metrics. For a nonbiological multienzymatic synthesis, the kinetic modeling of the individual reaction steps is crucial to evaluate the best enzymes and the optimal reactor configuration. This should be combined with fine tuning of the expression system to achieve the level of activities required of each enzyme within the cell. A limited number of such studies are reported in the literature, but this approach is highly valuable to speed up the transfer of technology to the industrial scale. ${ }^{22}$ One of the reported studies shows that individual reactions do not behave equally when combined, and if purified enzymes are employed, then a compatibility assessment with the intrinsic metabolism of the host cell must be performed prior to in vivo development. ${ }^{43}$ For that reason, we believe this kind of research is important.

\section{EXPERIMENTAL PART}

2.1. Chemicals. Formaldehyde (36\%, p.a.) was purchased from T.T.T. Ltd. (Croatia). Triethanolamine (TEA), $N$ (benzyloxycarbonyloxy)succinimide ( $\mathrm{CbzOSu})$, trifluoroacetic acid (TFA), L-homoserine, L-alanine, pyruvate, pyridoxal phosphate (PLP), and acetonitrile $\left(\mathrm{CH}_{3} \mathrm{CN}\right)$ were purchased from Sigma-Aldrich (Germany). O-Benzylhydroxylamine hydrochloride $\left(\mathrm{BnONH}_{2} \cdot \mathrm{HCl}\right)$ and pyridine were purchased from Acros Organics (Belgium). Lyophilized E. coli cells Yfau (013)/PROTRANS (039) containing coexpressed transaminase 039 (TA 039) (E.C. 2.6.1.2) and YfaU 013 aldolase (YfaU 013) (E.C. 4.1.2.53) were prepared and supplied by Prozomix Ltd. (United Kingdom). 4-Hydroxy-2-oxobutanoate was synthesized and purified in the labs of IQAC-CSIC (Barcelona, Spain) and the Faculty of Chemical Engineering and Technology at the University of Zagreb (Croatia).

2.2. High-Performance Liquid Chromatography (HPLC) Analysis. The reaction was monitored by HPLC with UV detection (Prominence, Shimadzu, Japan) at $215 \mathrm{~nm}$ and at $30{ }^{\circ} \mathrm{C}$. Precolumn derivatization of pyruvate, formaldehyde, and 4-hydroxy-2-oxobutanoate with $\mathrm{BnONH}_{2} \cdot \mathrm{HCl}$ was required before the analysis. L-Alanine and L-homoserine were derivatized with $\mathrm{CbzOSu}$ before the analysis. Details of the procedure, ${ }^{42}$ as well as the analytical method, are described in the literature. ${ }^{18}$

2.3. Activity of Transaminase and Aldolase. Transaminase and aldolase activities within the LWCB were determined using the initial reaction rate method in a 1.0 $\mathrm{mL}$ batch reactor with 5 and $0.2 \mathrm{mg} \mathrm{mL}^{-1}$ of lyophilized cells, respectively, in $50 \mathrm{mM}$ phosphate buffer $\mathrm{pH} 7.0$ at $25^{\circ} \mathrm{C}$ on a shaker at $1000 \mathrm{rpm}$. The linear slope, estimated from the change in product concentration at the beginning of the reaction when substrate conversion was $<10 \%$, was used to calculate the specific enzyme activity (S.A.) presented in eq 1 . The concentration of cells required for the enzyme activity assay was determined based on the preliminary measurements in which the concentrations of the cells were $0,1,5$, and $10 \mathrm{mg}$ $\mathrm{mL}^{-1}$. Preliminary measurements for the aldolase were carried out at $100 \mathrm{mM}$ concentrations of pyruvate and formaldehyde, whereas for transaminase, $100 \mathrm{mM}$ concentrations of $\mathrm{L}$ homoserine and pyruvate were used 

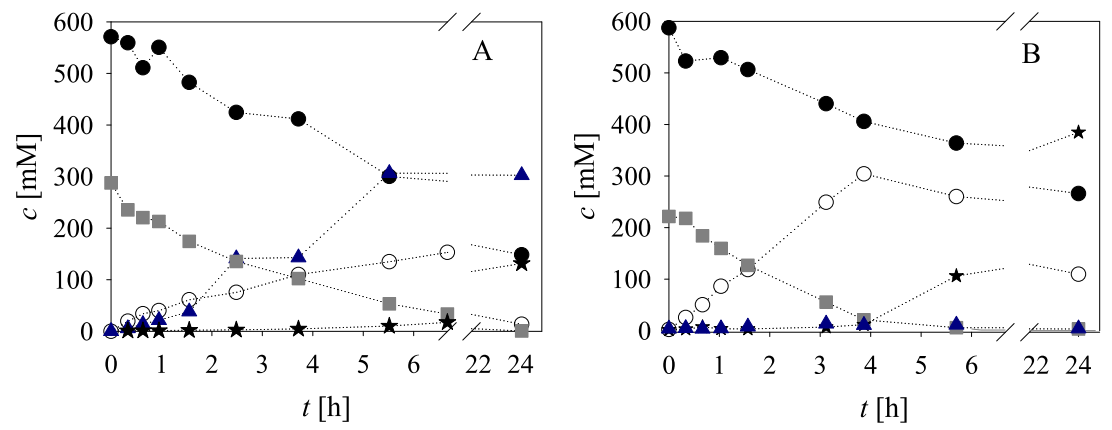

Figure 1. Cascade reactions performed in the fed-batch reactor $\left(V_{0}=7.8 \mathrm{~mL}, 50 \mathrm{mM}\right.$ phosphate buffer $\mathrm{pH} 7.0,25^{\circ} \mathrm{C}, 450 \mathrm{rpm}, c_{\text {formaldehyde,feed }}=3.1$

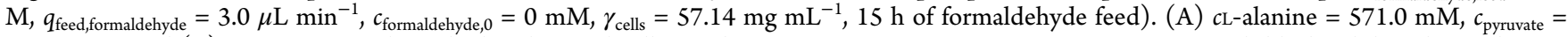
$287.7 \mathrm{mM}$; and (B) experiment with washed and reused cells; $c \mathrm{~L}$-alanine $=508.4 \mathrm{mM}, c_{\text {pyruvate }}=221.5 \mathrm{mM}$. Legend: black solid circles, L-alanine; gray solid squares, pyruvate; blue solid triangles, L-homoserine; open circles, 4-hydroxy-2-oxobutanoate; and black solid stars, formaldehyde.

$$
\text { S. A. }=\frac{\mathrm{d} c_{\text {product }}}{\mathrm{d} t} \cdot \frac{V_{\mathrm{r}}}{V_{\text {cells }}} \cdot \frac{1}{\gamma_{\text {cells }}} \quad\left(\mathrm{U} \mathrm{mg}_{\text {cells }}{ }^{-1}\right)
$$

The kinetics of the reactions in the cascade system (Scheme 1) was determined for each enzymatic reaction separately, also considering the influence of the reaction compounds not directly present in the separate reactions. Even though LWCB contains both enzymes (i.e., aldolase and transaminase), measurements were carried out in such a way as to prevent the interference of the other enzyme. These measurements with LWCB include the kinetics of (i) transamination catalyzed by TA 039 , (ii) reverse transamination catalyzed by TA 039 , (iii) aldol addition catalyzed by $\mathrm{YfaU} 013$, and (iv) retro-aldol reaction catalyzed by $\mathrm{YfaU}$ 013. Details of the experimental conditions are presented in the Supporting Information (SI) figure legends (Figures S2-S4). Considering that cells contain enough endogenous PLP, ${ }^{44-46}$ it was not necessary to add this cofactor in the kinetic measurements or in the cascade reactions catalyzed by lyophilized cells.

The influence of each reaction compound on the initial reaction rate, i.e., enzyme-specific activity, was examined by keeping the concentrations of other compounds constant. A series of the batch reactor experiments were carried out for that purpose, in which the change in product concentration was monitored by HPLC. Considering the previous knowledge on this particular enzymatic cascade system, ${ }^{18}$ it was not necessary to investigate the influence of all compounds, as it was expected that certain compounds will have no influence on the reaction rate. For example, this was the case for methanol, which was found to inhibit transaminase in forward and reverse reactions, but the inhibition was not very significant, and was disregarded here. Additionally, the influence of formaldehyde in the reverse transaminase-catalyzed reaction could not be measured because of its fast reaction with pyruvate. Thus, the previously estimated kinetic parameter from the CFE system was used in this case as well. As far as the YfaU 013 is concerned, the kinetic parameters for the second aldol addition were not investigated here but were taken from the CFE system. This was elaborated in detail in the Supporting information (Sections S1 and S2).

2.4. Stability of the Reaction Components in Buffer in the Absence and Presence of LWCB. The stability of the reaction components in the reaction mixture was compared in the presence and absence of cells. Single compounds at different concentrations, i.e., L-homoserine, L-alanine, and pyruvate, as well as the combination of pyruvate and L-alanine, were incubated in $50 \mathrm{mM}$ sodium phosphate buffer $\mathrm{pH} 7.0$ and at $25{ }^{\circ} \mathrm{C}$ shaken at $1000 \mathrm{rpm}$ in a $1 \mathrm{~mL}$ reaction volume in Eppendorf tubes. Their concentration was followed for several hours, and from the initial part, the initial reaction rates of their consumption were estimated. In these experiments, the concentration of cells was always $50 \mathrm{mg} \mathrm{mL}{ }^{-1}$. Hence, the reaction components, single and combined, were tested with and without the presence of cells to evaluate whether there were any additional significant background reactions, besides those already reported previously, i.e., 4-hydroxy-2-oxobutanoate and pyruvate side reactions. ${ }^{18}$

2.5. Fed-Batch Experiments Catalyzed by LWCB. Several fed-batch cascade experiments were performed at different conditions in the apparatus presented in Section S5, SI. The initial volume was always $7.8 \mathrm{~mL}$. Formaldehyde was fed to the reactor for $15 \mathrm{~h}$ at $3 \mu \mathrm{L} \mathrm{min}{ }^{-1}$, unless stated otherwise, from a stock solution (3.1 M) (commercial). A syringe pump (PHD 4400 Syringe Pump Series, Harvard Apparatus) with a high-pressure stainless steel piston $(8 \mathrm{~mL}$, Harvard Apparatus) was used for that purpose. Initial pyruvate and L-alanine concentrations were always approx. 250 and 500 $\mathrm{mM}$, respectively. Experiments were carried out with different concentrations of lyophilized cells, i.e., ca. 51 and $76 \mathrm{mg} \mathrm{mL}^{-1}$, and conducted in a glass jacketed reactor at $25^{\circ} \mathrm{C}$ on a shaker at $450 \mathrm{rpm}$ in $50 \mathrm{mM}$ phosphate buffer $\mathrm{pH}$ 7.0. Specific experimental details are given in the legends of Figures 1-4. In some reactions, concentrations of pyruvate and sometimes $\mathrm{L}^{-}$ alanine were increased after $6.5 \mathrm{~h}$ by adding fresh chemicals in the amounts up to their initial concentration. In the final fedbatch reaction, fresh pyruvate and L-alanine were added after 6.5 and $13.2 \mathrm{~h}$ (details presented in the Figure 4 legend). Part of the experiments was planned according to our previous findings based on the mathematical model of the CFE system. ${ }^{18}$

2.6. Mathematical Model and Data Handling. The kinetic model for LWCB was based on the measurements of enzyme kinetics and considering some of the features found for the CFE system. ${ }^{18}$ The reaction rate of the TA 039-catalyzed transamination of 4-hydroxy-2-oxobutanoate with L-alanine $\left(r_{1}\right)$ was described by the double-substrate Michaelis-Menten equation. Unlike CFE, in this case, no substrate inhibition by 4-hydroxy-2-oxobutanoate was detected and it was thus eliminated from the equation. The equation also included competitive inhibitions by sodium pyruvate and formaldehyde (eq 2, Table 1a). Methanol inhibition was excluded from the equation due to its irrelevance, as shown in the enzymatic 
Table 1a. Mathematical Model for the Cascade Reaction System: Kinetic Equations

Kinetic Equations

TA 039-Catalyzed Reaction

$$
\begin{aligned}
r_{1}= & {\left[V_{\mathrm{m} 1} \cdot \gamma_{\text {cells }} \cdot c_{\mathrm{L}-\text { alanine }} \cdot c_{4-\text { hydroxy-2-oxobutanoate }}\right] } \\
& /\left(K_{\mathrm{m} 1 \mathrm{~L}-\text { alanine }} \cdot\left(1+\frac{c_{\text {pyruvate }}}{K_{\mathrm{i} 1 \text { pyruvate }}}+\frac{c_{\text {formaldehyde }}}{K_{\mathrm{i} 1, \text { formaldehyde }}}\right)+c_{\mathrm{L}-\text { alanine }}\right) \\
& \left.\left(K_{\mathrm{m} 1,4 \text {-hydroxy }-2 \text {-oxobutanoate }}+c_{4-\text { hydroxy-2-oxobutanoate }}\right)\right] \\
r_{2}= & {\left[V_{\mathrm{m} 2} \cdot \gamma_{\text {cells }} \cdot c_{\mathrm{L}-\text { homoserine }} \cdot c_{\text {pyruvate }}\right] } \\
& /\left(K_{\mathrm{m} 2, \mathrm{~L}-\text { homoserine }} \cdot\left(1+\frac{c_{4-\text { hydroxy-2-oxobutanoate }}}{K_{\mathrm{i} 2,4-\text { hydroxy-2-oxobutanoate }}}\right)+c_{\mathrm{L}-\text { homoserine }}\right) \\
& \left.\left(K_{\mathrm{m} 2, \text { pyruvate }} \cdot\left(1+\frac{c_{\text {formaldehyde }}}{K_{\mathrm{i} 2, \text { formaldehyde }}}+\frac{c_{\mathrm{L}-\text { alanine }}}{K_{\mathrm{i} 2, \mathrm{~L}-\text { alanine }}}\right)+c_{\text {pyruvate }}\right)\right]
\end{aligned}
$$

$$
\text { YfaU 013-Catalyzed Reaction }
$$

$$
\begin{aligned}
r_{3}= & {\left[V_{\mathrm{m} 3} \cdot \gamma_{\text {cells }} \cdot c_{\text {pyruvate }} \cdot c_{\text {formaldehyde }}\right] } \\
& \int\left(K_{\mathrm{m} 3 \text {,pyruvate }} \cdot\left(1+\frac{c_{\mathrm{L}-\text { homoserine }}}{K_{\mathrm{i} 3 \mathrm{~L}-\text {-homoserine }}}+\frac{c_{\mathrm{L}-\text { alanine }}}{K_{\mathrm{i} 3, \mathrm{~L}-\text { alanine }}}\right)+c_{\text {pyruvate }}\right. \\
& \left.\left.+\frac{c_{\text {pyruvate }}^{2}}{K_{\mathrm{i} 3 \text {,pyruvate }}}\right) \cdot\left(K_{\mathrm{m} 3 \text {,formaldehyde }}+c_{\text {formaldehyde }}+\frac{c_{\text {formaldehyde }}^{2}}{K_{\mathrm{i} 3, \text { formaldehyde }}}\right)\right] \\
r_{4}= & \frac{V_{\mathrm{m} 4} \cdot \gamma_{\text {cells }} \cdot c_{4-\text { hydroxy-2-oxobutanoate }}}{K_{\mathrm{m} 4,4-\text { hydroxy-2-oxobutanoate }} \cdot\left(1+\frac{c_{\text {pyruvate }}}{K_{\mathrm{i} 4, \text { pyruvate }}}\right)+c_{4-\text { hydroxy-2-oxobutanoate }}}
\end{aligned}
$$

Aldol Addition of Formaldehyde to 4-Hydroxy-2-oxobutanoate

$$
\begin{aligned}
r_{5}= & {\left[k_{5} \cdot \gamma_{\text {cells }} \cdot c_{\text {formaldehyde }} \cdot c_{4-\text { hydroxy-2-oxobutanoate }}\right] } \\
& /\left(\left[K_{\mathrm{m} 5 \text {,formaldehyde }}+c_{\text {formaldehyde }}+\frac{c_{\text {formaldehyde }}^{2}}{K_{\mathrm{i} 5 \text {,formaldehyde }}}\right) .\right. \\
& \left.\left(1+\frac{c_{\mathrm{L}-\text { homoserine }}}{K_{\mathrm{i} 5, \mathrm{~L}-\text { homoserine }}}+\frac{c_{\mathrm{L}-\text { alanine }}}{K_{\mathrm{i} 5, \mathrm{~L} \text {-alanine }}}+\frac{c_{\text {pyruvate }}}{K_{\mathrm{i} 5 \text {,pyruvate }}}\right)\right]
\end{aligned}
$$

Unspecific Transformation of 4-Hydroxy-2-oxobutanoate

$$
r_{6}=k_{6} \cdot c_{4-\text { hydroxy }-2 \text {-oxobutanoate }}
$$

Biotransformation of Pyruvate Catalyzed by LWCB

$$
r_{7}=\frac{V_{\mathrm{m} 7} \cdot c_{\text {pyruvate }} \cdot \gamma_{\text {cells }}}{K_{\mathrm{m} 7}^{\text {pyruate }}+c_{\text {pyruvate }}}
$$

Biotransformation of L-Alanine Catalyzed by LWCB

Biotransformation of L-Homoserine Catalyzed by LWCB

Operational Stability Decay Rate

$$
r_{8}=\frac{V_{\mathrm{m} 8} \cdot c_{\mathrm{L}-\text { alanine }} \cdot \gamma_{\text {cells }}}{K_{\mathrm{m} 8}^{\mathrm{L}-\text { alanine }}+c_{\mathrm{L}-\text { alanine }}+\frac{c_{\mathrm{L}-\text { alanine }}^{\mathrm{L}}}{K_{\mathrm{i} 8}^{\mathrm{L}-\text { alanine }}}}
$$

$$
V_{\mathrm{m}}=V_{\mathrm{m} 0} \mathrm{e}^{-k_{\mathrm{d}} \cdot t}
$$

system. ${ }^{18}$ It was assumed that the PLP concentration within the cells is enough to obtain maximum enzyme activity. Therefore, it was not regarded as relevant in this model. The reaction rate of the reverse TA 039-catalyzed reaction between pyruvate and L-homoserine $\left(r_{2}\right)$ remained the same as in the system with CFE and was described by the double-substrate Michaelis-Menten equation with competitive inhibitions by 4hydroxy-2-oxobutanoate, formaldehyde, and L-alanine. However, in this case, the impact of the PLP concentration and the noncompetitive inhibition by methanol were neglected (eq 3, Table 1a).

The kinetic model for the YfaU 013 catalysis was found to be the same as for the CFE system. The reaction rate of $\mathrm{YfaU}$ 013-catalyzed aldol addition of formaldehyde to pyruvate $\left(r_{3}\right)$ was described by the double-substrate Michaelis-Menten equation with substrate inhibition by formaldehyde and pyruvate, as well as competitive inhibition by L-alanine and L-homoserine (eq 4, Table 1a). The reaction rate of the retroaldol reaction $\left(r_{4}\right)$ was described by the Michaelis-Menten kinetics with competitive inhibition by pyruvate (eq 5 , Table 1a). The reaction rate of the second aldol addition of 4hydroxy-2-oxobutanoate to formaldehyde catalyzed by YfaU $013\left(r_{5}\right)$ was not measured in this work but was taken from the CFE system where the rate of this reaction was found to linearly depend on the 4-hydroxy-2-oxobutanoate (eq 6, Table 1a). Unspecific nonenzymatic transformation of 4-hydroxy-2oxobutanoate was also included in the model, as in the previous work. Its reaction rate $\left(r_{6}\right)$ was described by the kinetics of the first order (eq 7, Table 1a). Side consumption of pyruvate, which was detected in our previous work, yielded L- 
alanine and was monitored more closely in this work (Section S3, SI). It was found that this biotransformation is catalyzed by the enzyme present within the cells. According to the Kyoto Encyclopedia of Genes and Genomes (KEGG) database, ${ }^{47}$ some enzymes from the alanine metabolism could be responsible for that biotransformation, but this was not further investigated. Nevertheless, the reaction rate $\left(r_{7}\right)$ of this biotransformation can be described by the Michaelis-Menten kinetics (eq 8, Table 1a). It was found that L-alanine is also biotransformed and that the dependence of the reaction rate on L-alanine concentration $\left(r_{8}\right)$ can be described by the Michaelis-Menten kinetics with substrate inhibition (eq 9, Table 1a). In the longer experiments, it was observed that Lhomoserine was also transformed, probably to L-threonine and L-methionine. ${ }^{37}$ The reaction rate of L-homoserine transformation $\left(r_{9}\right)$ was described by the Michaelis-Menten kinetics (eq 10, Table 1a and Section S3, SI). The operational stability decay rate of both enzymes was assumed to behave according to the kinetics of the first order (Table 1a, eq 11).

Mass balance equations in the fed-batch reactor for the cascade system are represented by eqs $12-17$ (Table 1b). Equation 18 (Table $1 \mathrm{~b}$ ) represents the change in the reactor volume during the experiment defined by the flow rate of formaldehyde solution.

Table 1b. Mathematical Model for the Cascade Reaction System: Mass Balance Equations

$$
\begin{aligned}
& \text { mass balances in the fed-batch reactor } \\
& \frac{\mathrm{d} c_{\mathrm{L}-\text { alanine }}}{\mathrm{d} t}=\frac{1}{V} \cdot\left(-c_{\mathrm{L} \text {-alanine }} \cdot \frac{\mathrm{d} V}{\mathrm{~d} t}\right)-r_{1}+r_{2}+r_{7}-r_{8} \\
& \frac{\mathrm{d} c_{4-\text { hydroxy-2-oxobutanoate }}}{\mathrm{d} t}=\frac{1}{V} \cdot\left(-c_{4 \text {-hydroxy-2-oxobutanoate }} \cdot \frac{\mathrm{d} V}{\mathrm{~d} t}\right) \\
& -r_{1}+r_{2}+r_{3}-r_{4}-r_{5}-r_{6} \\
& \frac{\mathrm{d} c_{\mathrm{L}-\text { homoserine }}}{\mathrm{d} t}=\frac{1}{V} \cdot\left(-c_{\mathrm{L} \text {-homoserine }} \cdot \frac{\mathrm{d} V}{\mathrm{~d} t}\right)+r_{1}-r_{2}-r_{9} \\
& \frac{\mathrm{d} c_{\text {pyruvate }}}{\mathrm{d} t}=\frac{1}{V} \cdot\left(-c_{\text {pyruvate }} \cdot \frac{\mathrm{d} V}{\mathrm{~d} t}\right)+r_{1}-r_{2}-r_{3}+r_{4}-r_{7}+r_{8} \\
& \frac{\mathrm{d} c_{\text {formaldehyde }}}{\mathrm{d} t}=\frac{1}{V} \cdot\left(-c_{\text {formaldehyde }} \cdot \frac{\mathrm{d} V}{\mathrm{~d} t}+c_{\text {formaldehyde, } 0} \cdot q\right)-r_{3}+r_{4} \\
& \frac{\mathrm{d} \gamma_{\text {cells }}}{\mathrm{d} t}=\frac{1}{V} \cdot\left(-\gamma_{\text {cells }} \cdot \frac{\mathrm{d} V}{\mathrm{~d} t}\right) \\
& \frac{\mathrm{d} V}{\mathrm{~d} t}=q
\end{aligned}
$$

All kinetic parameters, $V_{\mathrm{m}}, K_{\mathrm{m}}$, and $K_{\mathrm{i}}$, were estimated from the experimental data, i.e., sets of specific enzyme activity within the whole cells vs concentration, collected using the initial reaction rate method. Nonlinear regression methods (simplex and least-squares fit) implemented in SCIENTIST software were used for parameter estimation. ${ }^{48}$ The same software was used for model simulations.

\section{RESULTS AND DISCUSSION}

The cascade synthesis of L-homoserine with CFE was studied previously, and modeling was found to be crucial for better understanding of the reaction system, as well as for successful process optimization. ${ }^{18}$ Benefits of the synergistic approach that combines biochemical knowledge and process modeling were demonstrated there. ${ }^{18}$ In the present work, LWCBs were applied. Using the findings from our previous work, ${ }^{18,42}$ the two enzymes were coexpressed in E. coli in a level to achieve the required ratio of the aldolase/transaminase activity, a crucial parameter for the process optimization. Model simulations have shown that the required aldolase/transaminase activity ratio should be as low as possible to obtain the maximum concentration of L-homoserine (Figure S7, SI). The ultimate goal of this work was to evaluate the LWCB, as well as to establish the similarities and differences regarding the process metrics with the reaction catalyzed by CFE. This would offer a process improvement considering that LWCB is cheaper than free enzymes and CFE, and there is no need to add expensive PLP to the reactor, considering its natural presence within the cells. Additionally, an improved stability in comparison to free enzymes and excellent performance of enzymes within cells has been documented in the literature, ${ }^{49-51}$ and this is also expected in the process investigated in this work. It was expected that the reaction performance would be similar to CFE. Therefore, reaction kinetics with LWCB was thoroughly studied and compared with the kinetics of CFE. As side reactions occurred when CFEs were used, it was assumed that this would also be the case when using LWCB. Thus, the experimental effort was focused on the potential side reactions and to predict their effect on the reaction outcome via process modeling and simulations. The key difference between the CFE and LWCB is the presence of

\begin{tabular}{|c|c|c|c|c|c|c|}
\hline $\exp$ no & conditions & $\begin{array}{l}n \mathrm{~L} \text {-homoserine } \\
\quad(\mathrm{mmol})\end{array}$ & $\begin{array}{l}n_{\text {pyruvate }, 0} \\
(\mathrm{mmol})\end{array}$ & $\begin{array}{l}n_{\text {pyruvate,end }} \\
\text { mmol) }\end{array}$ & $\begin{array}{c}n_{\text {pyruvate, net }} \\
\text { mmol) }\end{array}$ & $\begin{array}{l}\% \text { pyruvate } \\
\text { spent }\end{array}$ \\
\hline Figure $1 \mathrm{~A}$ & & 2.696 & 2.24 & 0.468 & 1.772 & 79.1 \\
\hline Figure $1 \mathrm{~B}$ & reused cells & 0.089 & 1.728 & 0.046 & 1.682 & 97.3 \\
\hline Figure $2 \mathrm{~A}$ & $\begin{array}{l}\text { pyruvate concentration kept at } 50 \mathrm{mM} \text {, formaldehyde feed } \\
\quad 1 \mu \mathrm{L} \mathrm{min}^{-1}\end{array}$ & 1.322 & 2.311 & 0.146 & 2.165 & 93.7 \\
\hline Figure $2 \mathrm{~B}$ & pyruvate concentration kept at $100 \mathrm{mM}$ & 2.446 & 3.857 & 0.734 & 3.123 & 81.0 \\
\hline Figure & subsequent addition of pyruvate & 3.02 & 4.452 & 0.348 & 4.103 & 92.2 \\
\hline Figure $3 \mathrm{~A}$ & subsequent addition of L-alanine and pyruvate, $1 \times$ & 4.183 & 4.247 & 0.654 & 3.829 & 90.2 \\
\hline Figure $3 \mathrm{~B}$ & subsequent addition of $\mathrm{L}$-alanine and pyruvate, $1 \times$ & 4.192 & 4.429 & 0.604 & 3.645 & 82.3 \\
\hline Figure 4 & subsequent addition of L-alanine and pyruvate, $2 \times$ & 7.686 & 4.144 & 0.766 & 3.378 & 81.2 \\
\hline
\end{tabular}
a cell wall and membrane that can act as natural support for enzymes. Diffusional problems were not detected with LWCB, which indicated a normal transport of substrates/products and retention of enzyme activity inside the membrane. This is mostly because during the freezing-drying process, the cell wall and the membrane are damaged, though the cells retain some enzymatic activity. ${ }^{52}$ The results obtained in this paper

Table 2. Overview of Pyruvate Recycling for the Conducted Experiments 
Table 3. Overview of the Important Process Metrics for the Conducted Experiments

\begin{tabular}{|c|c|c|c|c|c|c|c|}
\hline $\exp$ no & conditions & $t(\mathrm{~h})$ & $\begin{array}{c}n \mathrm{~L} \text {-homoserine } / \\
n_{\text {pyruvate,net }}\end{array}$ & $\left(\begin{array}{c}\gamma_{\text {cells }} \\
\left(\mathrm{g} \mathrm{L}^{-1}\right)\end{array}\right.$ & $\begin{array}{c}\gamma_{\mathrm{L}-\text { homoserine }} \\
\left(\mathrm{g} \mathrm{L}^{-1}\right)\end{array}$ & $\left(\mathrm{g} \mathrm{L}^{-1} \mathrm{Q}^{-1}\right)$ & $\begin{array}{c}Y_{\text {biocatalyst }} \\
\left(\mathrm{g} \mathrm{g}^{-1}\right)\end{array}$ \\
\hline $\begin{array}{l}\text { Figure } \\
\text { 1A }\end{array}$ & & 5.52 & 1.52 & 57.14 & 36.03 & 6.53 & 0.63 \\
\hline $\begin{array}{l}\text { Figure } \\
\text { 1B }\end{array}$ & reused cells & 5.70 & 0.05 & 57.14 & 1.36 & 0.24 & 0.02 \\
\hline $\begin{array}{l}\text { Figure } \\
2 \mathrm{~A}\end{array}$ & $\begin{array}{l}\text { pyruvate concentration kept at } 50 \mathrm{mM} \text {, formaldehyde } \\
\text { feed } 1 \mu \mathrm{L} \mathrm{min}-1\end{array}$ & 6.17 & 0.61 & 76.28 & 19.32 & 3.12 & 0.25 \\
\hline $\begin{array}{l}\text { Figure } \\
2 \mathrm{~B}\end{array}$ & pyruvate concentration kept at $100 \mathrm{mM}$ & 9.18 & 0.78 & 76.60 & 28.48 & 3.10 & 0.37 \\
\hline $\begin{array}{l}\text { Figure } \\
2 \mathrm{C}\end{array}$ & subsequent addition of pyruvate & 11.92 & 0.74 & 57.35 & 36.20 & 3.04 & 0.63 \\
\hline $\begin{array}{l}\text { Figure } \\
3 \mathrm{~A}\end{array}$ & subsequent addition of L-alanine and pyruvate, $1 \times$ & 24 & 1.09 & 57.38 & 47.45 & 1.98 & 0.83 \\
\hline $\begin{array}{l}\text { Figure } \\
3 \mathrm{~B}\end{array}$ & subsequent addition of L-alanine and pyruvate, $1 \times$ & 25 & 1.15 & 76.23 & 47.56 & 1.90 & 0.62 \\
\hline Figure 4 & subsequent addition of L-alanine and pyruvate, $2 \times$ & 29.25 & 2.28 & 76.30 & 76.33 & 2.61 & 1.00 \\
\hline
\end{tabular}

are divided into five chapters including LWCB enzyme kinetics with side reactions, fed-batch reactor experiments (Figures 1-4 and Table 2), and modeling and simulations of experiments presented in Figures 5 and 6 with the corresponding process metrics in Table 3.

3.1. Kinetics of Enzymes within LWCB. A detailed kinetic analysis of LWCB was carried out (Sections S1 and S2, SI). The results show that within the cells some inhibitions are changed when compared with the results with CFE. For example, TA 039 as CFE was slightly inhibited by 4-hydroxy-2oxobutanoate as a substrate, whereas the inhibition was not

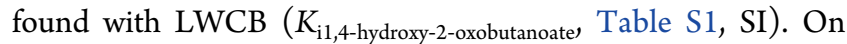
the other hand, the inhibition of TA 039 in LWCB by

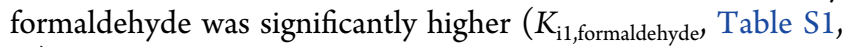
SI) than that with CFE. In some cases, the apparent affinity of TA 039 in LWCB toward the substrate was lower $\left(K_{\mathrm{m} 2 \text {,pyruvate, }}\right.$ Table S1, SI $)$ and in some cases higher $\left(K_{\mathrm{m} 1} \mathrm{~L}\right.$-alanine, Table $\mathrm{S} 1, \mathrm{SI})$ than the affinity in CFE. In the case of YfaU 013, except for the Michaelis constant for 4-hydroxy-2-oxobutanoate ( $K_{\mathrm{m} 4,4 \text {-hydroxy-2-oxobutanoate, }}$ Table S2, SI), which was lower in LWCB, all other kinetic parameters are similar to CFE. The results (Tables S1 and S2, SI) also show that a similar model can be used to simulate the two-enzyme cascade catalyzed by LWCB and CFE, as was anticipated. Indeed, our previously reported results ${ }^{18}$ provide an excellent basis to study the performance with LWCB, consistent with another example reported for the living cells. ${ }^{13}$

3.2. Stability of Reaction Components during Incubation with Cells. In view of the complexity of working with LWCB instead of CFE, experiments were done to evaluate the stability of the reaction components in the presence of LWCB and to evaluate their potential impact on the biocatalytic cascade process. The retention of some enzymatic activities of the lyophilized cells is an important difference of the LWCB system in comparison to CFE. Since pyruvate is an important compound of the central cell metabolism, investigation of the potential pyruvate side reactions was conducted to assess their influence on the outcome of the process. Detailed analysis of the results is presented in Section S3, SI. It was observed that L-homoserine, L-alanine, and pyruvate are slowly consumed by LWCB, which starts immediately after mixing with freshly thawed cells. Individual experiments indicated that the rate of L-homoserine consumption is by far the slowest and is influenced by its concentration. The dependence of the specific activity of
LWCB on the concentration of L-homoserine shows a clear Michaelis-Menten pattern (Figure S5A, SI). However, the estimated kinetic parameters (Table S3, SI) indicated low activity of LWCB even at high L-homoserine concentrations. Thus, it could be concluded that this reaction should not be significant for the cascade process and should not cause significant product loss for relatively short reaction times. Similar experiments carried out with L-alanine indicated the existence of enzymatic reaction with substrate inhibition

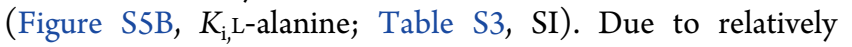
low activities in L-alanine biotransformation at concentrations higher than $100 \mathrm{mM}$ (Figure S5B, SI), it is expected that this reaction will not have a significant influence on the cascade reaction. Experiments with pyruvate showed that it is more rapidly transformed than the other two compounds. The dependence of specific activity on its concentration (Figure S5C, SI) shows a typical Michaelis-Menten kinetics (Figure S5C, SI). The apparent kinetic constants (Table S3, SI) indicated that this reaction could present a more significant side reaction, especially at concentrations above $100 \mathrm{mM}$, which was the concentration used in the cascade reaction experiments. Additional experiments (Figure S6, SI) revealed that LWCB transforms pyruvate to L-alanine and it was concluded that it is most likely the activity of an enzyme from alanine metabolism. ${ }^{47}$ Therefore, the rate of biotransformations of pyruvate $\left(r_{7}\right.$, Table 1a), L-alanine $\left(r_{8}\right.$, Table 1a), and Lhomoserine $\left(r_{9}\right.$, Table 1a) was included in the model, i.e., mass balances for pyruvate, L-alanine, and L-homoserine (eqs 15, 12, and 14, Table $1 \mathrm{~b})$.

3.3. Fed-Batch Reactor Experiments. The first part of the experiments, presented in this chapter, was carried out to investigate the reusability of $\mathrm{LWCB}$, the effect of different ways of pyruvate addition to pyruvate recycling efficiency, and the effect of addition of both substrates, prior to reaction modeling. It was the purpose of this work to investigate if the same process metrics can be reached with LWCB. The main advantage of LWCB in comparison to that of CFE is primarily in its price. ${ }^{53,54}$ However, in this case, side reactions could present a more serious problem in practice. In the enzymatic cascade system using CFE, $80.1 \mathrm{~g} \mathrm{~L}^{-1}$ of $\mathrm{L}^{-}$ homoserine was obtained with a volume productivity of $3.2 \mathrm{~g}$ $\mathrm{L}^{-1} \mathrm{~h}^{-1}$ after $25 \mathrm{~h}$. Similar methodology ${ }^{18}$ was also applied here, as it was expected that the rules of behavior, i.e., model describing the system, would be very similar. Considering the negative effect of formaldehyde on the transaminase activity, as 

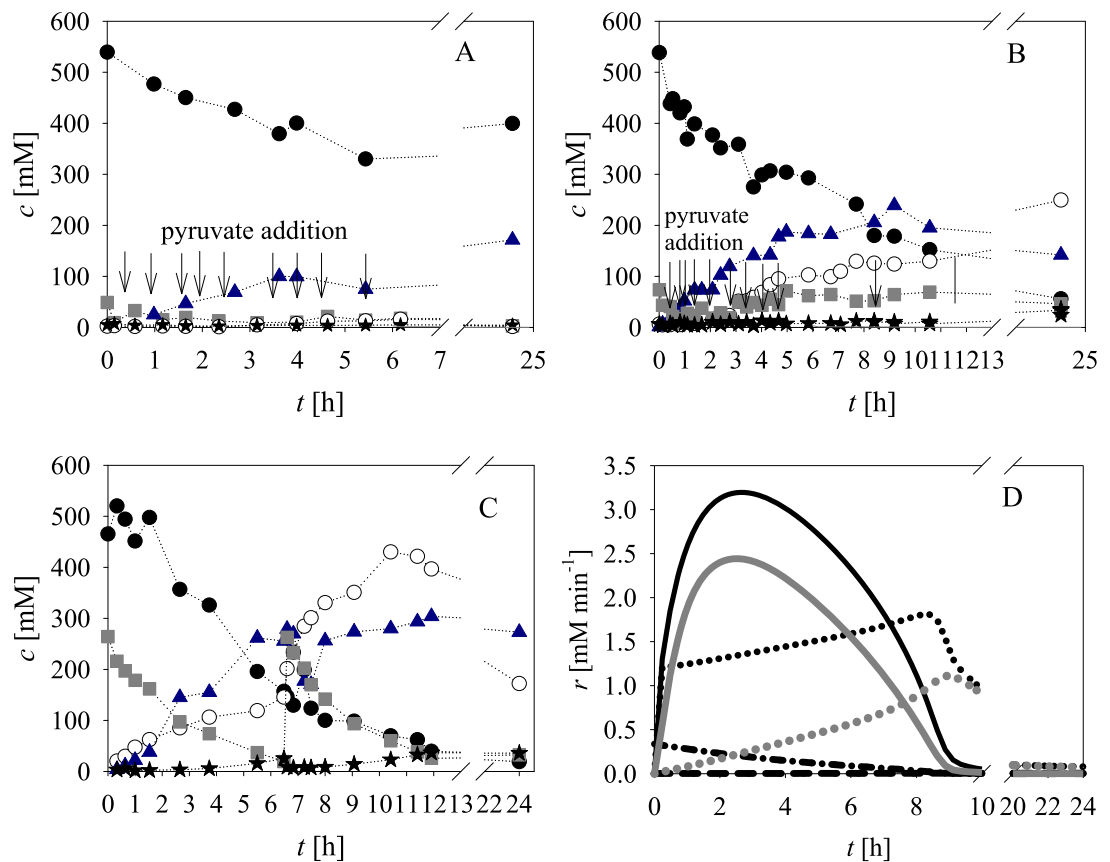

$t[\mathrm{~h}]$

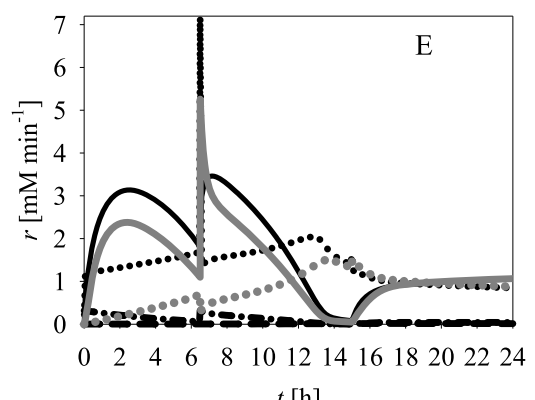

$t[\mathrm{~h}]$

Figure 2. Cascade reactions performed in the fed-batch reactor $\left(V_{0}=7.8 \mathrm{~mL}, 50 \mathrm{mM}\right.$ phosphate buffer $\mathrm{pH} 7.0,25^{\circ} \mathrm{C}, 450 \mathrm{rpm}, c_{\text {formaldehyde,feed }}=3.1$ $\mathrm{M}, q_{\text {feed,formaldehyde }}=3.0 \mu \mathrm{L} \mathrm{min}{ }^{-1}, c_{\text {formaldehyde, } 0}=0 \mathrm{mM}, 15 \mathrm{~h}$ of formaldehyde feed) (A) at a concentration of pyruvate below $50 \mathrm{mM}$, which was added in amounts of ca. $25 \mathrm{mM}$ at times designated by arrows, $c$ L-alanine $=539.4 \mathrm{mM}, c_{\text {pyruvate }}=73.7 \mathrm{mM}, \gamma_{\text {cells }}=48.8 \mathrm{mg} \mathrm{mL}^{-1}$; $(\mathrm{B})$ at a concentration of pyruvate ca. between 50 and $100 \mathrm{mM}\left(c \mathrm{c}\right.$-alanine $\left.=538.5 \mathrm{mM}, c_{\text {pyruvate }}=48.78 \mathrm{mM}, \gamma_{\text {cells }}=76.60 \mathrm{mg} \mathrm{mL}^{-1}\right)$; and $(\mathrm{C})$ with the addition of pyruvate after $6.5 \mathrm{~h}, \mathrm{cL}$-alanine $=538.0 \mathrm{mM}, c_{\text {pyruvate }}=264.2 \mathrm{mM}, c_{\text {pyruvate }, 1}=262.8 \mathrm{mM}, \gamma_{\text {cells }}=57.35 \mathrm{mg} \mathrm{mL}^{-1}$. Legend: black solid circle, L-alanine; gray solid square, pyruvate; blue solid triangle, L-homoserine; open circle, 4-hydroxy-2-oxobutanoate; and black solid star, formaldehyde. Dependence of the reaction rates related to pyruvate recycling during the reaction at the conditions of the exp. presented (D) in Figure 1 and (E) in (C). Legend: $r_{1}$, black solid line; $r_{2}$, gray solid line; $r_{3}$, black solid circles, $r_{4}$, gray solid circles; $r_{7}$, dashed dotted line; and $r_{8}$, dashed line.

it was well demonstrated here in kinetic measurements

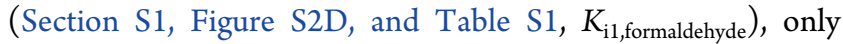
fed-batch reactor experiments with continuous addition of formaldehyde were considered.

The first experiment (Figure 1A) was performed at the reaction conditions very similar to CFE, and $36.5 \mathrm{~g} \mathrm{~L}^{-1}(306.4$ $\mathrm{mM}$ ) of L-homoserine was achieved after $5.5 \mathrm{~h}$. This is $50 \%$ better than using CFE (23.4 $\left.\mathrm{g} \mathrm{L}^{-1}, 196.2 \mathrm{mM}\right)$. After the first experiment was finished, the cells were centrifuged, washed with buffer, and reused in another experiment (Figure 1B). The reused cells gave ca. $1.2 \mathrm{~g} \mathrm{~L}^{-1}$ of L-homoserine, which indicated that the transaminase activity was extremely low. 4Hydroxy-2-oxobutanoate accumulated showing that the aldolase was still active. Hence, cells cannot be reused because transaminase loses its activity, which could be due to damage on the cell wall during freezing and thawing and loss of PLP during cell washing among other things.
3.4. Influence of Pyruvate Addition on the Process Outcome. The results obtained so far (Figure 1) show that pyruvate is spent after ca. $7 \mathrm{~h}$, but L-alanine still remained unreacted in the system, meaning that pyruvate recycling is not efficient. With the initial concentration of L-alanine at $571 \mathrm{mM}$ and efficient pyruvate recycling, one would theoretically expect the same final concentration of L-homoserine. Thus, further experiments were carried out to analyze the effect of pyruvate addition on the efficiency of its recycling, as well as on the reaction outcome. In the first experiment (Figure 2A), pyruvate concentration was kept below $50 \mathrm{mM}$ for $24 \mathrm{~h}$. To ensure this, sodium pyruvate concentration was added stepwise as a powder to the reactor at different time intervals (see the arrows in Figure 2A). In a second experiment (Figure 2B), the concentration of pyruvate was kept below $100 \mathrm{mM}$ by adding small portions of pyruvate. In a third experiment (Figure 2C), pyruvate was added when consumed (after $6.5 \mathrm{~h}$ ). It can be observed that the best result was accomplished when pyruvate 


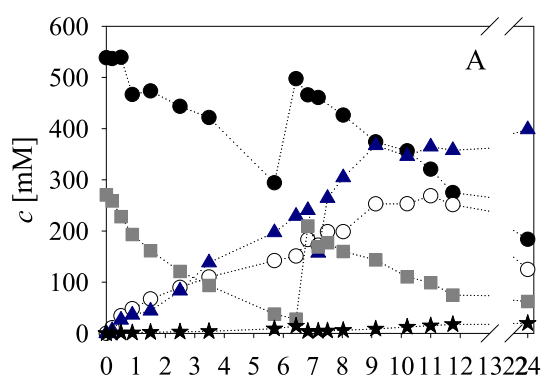

$t[\mathrm{~h}]$

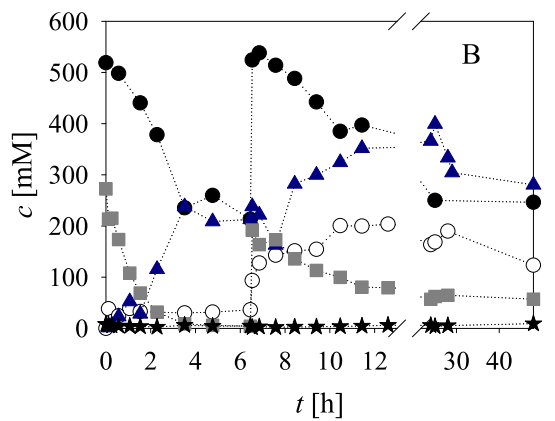

Figure 3. Cascade reactions performed in the fed-batch reactor $\left(V_{0}=7.8 \mathrm{~mL}, 50 \mathrm{mM}\right.$ phosphate buffer $\mathrm{pH} 7.0,25^{\circ} \mathrm{C}, 450 \mathrm{rpm}, c_{\text {formaldehyde,feed }}=3.1$

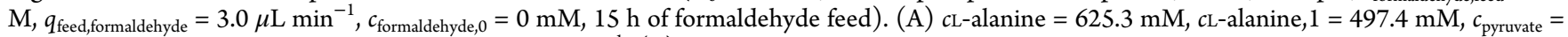
$270.33 \mathrm{mM}, c_{\text {pyruvate }, 1}=209.8 \mathrm{mM}, \gamma_{\text {cells }}=57.38 \mathrm{mg} \mathrm{mL}^{-1}$. (B) $c$ L-alanine $=518.9 \mathrm{mM}, c$ L-alanine, $1=538.1 \mathrm{mM}, c_{\text {pyruvate }}=272.5 \mathrm{mM}, c_{\text {pyruvate }, 1}=$ $192.2 \mathrm{mM}, \gamma_{\text {cells }}=76.23 \mathrm{mg} \mathrm{mL}{ }^{-1}$. Legend: black solid circles, L-alanine; gray solid squares, pyruvate; blue solid triangles, L-homoserine; open circles, 4-hydroxy-2-oxobutanoate; and black solid stars, formaldehyde.
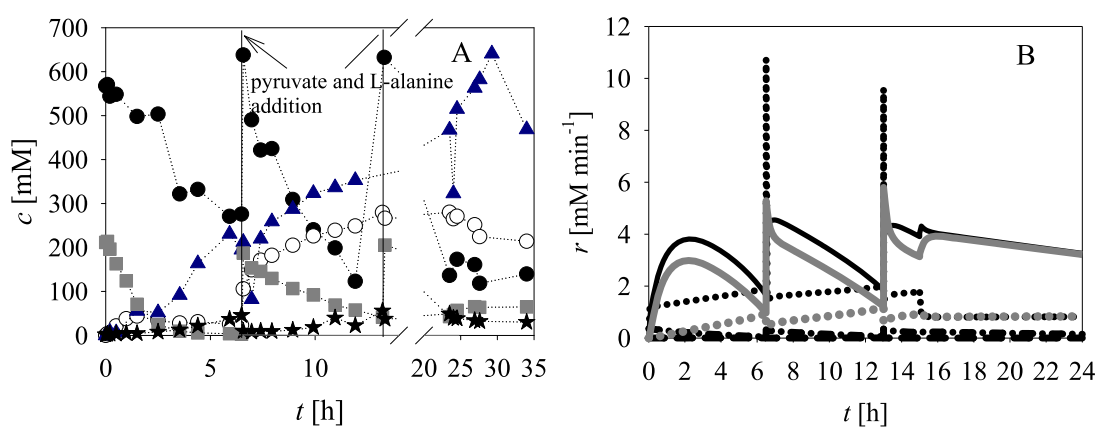

Figure 4. Cascade reactions performed in the fed-batch reactor with two additions of L-alanine and pyruvate $\left(V_{0}=7.8 \mathrm{~mL}, 50 \mathrm{mM}\right.$ phosphate buffer $\left.\mathrm{pH} 7.0,25^{\circ} \mathrm{C}, 450 \mathrm{rpm}, c_{\text {formaldehyde,feed }}=3.1 \mathrm{M}, q_{\text {feed,formaldehyde }}=3.0 \mu \mathrm{L} \mathrm{min}^{-1}\right) . c \mathrm{cL}$-alanine $=570.6 \mathrm{mM}, c \mathrm{~L}$-alanine, $1=637.8 \mathrm{mM}, c \mathrm{~L}$-alanine, $2=632.4 \mathrm{mM}, c_{\text {pyruvate }}=213.5 \mathrm{mM}, c_{\text {pyruvate }, 1}=187.5 \mathrm{mM}, c_{\text {pyruvate }, 2}=205.6 \mathrm{mM}, c_{\text {formaldehyde }, 0}=0 \mathrm{mM}, \gamma_{\text {cells }}=76.30 \mathrm{mg} \mathrm{mL}^{-1}, 15 \mathrm{~h}$ of formaldehyde feed. Legend: black solid circles, L-alanine; gray solid squares, pyruvate; blue solid triangles, L-homoserine; open circles, 4-hydroxy-2-oxobutanoate; and black solid stars, formaldehyde. (B) Dependence of the reaction rates related to pyruvate recycling during the reaction presented in panel (A). Legend: $r_{1}$, black solid line; $r_{2}$, gray solid line; $r_{3}$, black solid circles; $r_{4}$, gray solid circles; $r_{7}$, dashed dotted line; and $r_{8}$, dashed line.

was supplied once the initial concentration was consumed (Figure 2C), reaching $36.1 \mathrm{~g} \mathrm{~L}^{-1}(303 \mathrm{mM})$ of L-homoserine. This is similar to the experiment in Figure 1A. Regarding pyruvate recycling, the best results were obtained for the experiment presented in Figure 2B (Table 2), where $81 \%$ of pyruvate is spent, similarly to the experiment in Figure 1A. This clearly means that pyruvate was not recycled efficiently. If we discuss this from the point of reaction rates, i.e., $r_{1}$, transamination of L-alanine to L-homoserine; $r_{2}$, reverse transaminase reaction; $r_{3}$, aldol addition of pyruvate to formaldehyde; $r_{4}$, retro-aldol reaction; $r_{7}$, pyruvate biotransformation to L-alanine; and $r_{8}$, L-alanine biotransformation to pyruvate, the situation seems clearer. The reaction rate of the transaminase reaction, i.e., $r_{1}$, is the highest and the most significant in this cascade reaction system and they change over time (Figure 2D). As they start to decrease steeply to reach zero around the 9th hour of the experiment, the reaction rates of the $\mathrm{YfaU}$-reaction increase and are at the maximum at similar times. At that point, the maximum concentration of the aldol adduct is formed and cannot be spent due to a decrease of the rate of transamination. According to the reaction rate simulations, the reaction stops after reaching the maximum Lhomoserine concentration (approximately $10 \mathrm{~h}$ ). During the reaction, the side reaction $r_{7}$, which irreversibly spends pyruvate, is also present and decreases with time, whereas the reaction rate of the reverse reaction, $r_{8}$, is completely insignificant. The simulation of the reaction rates (Figure $2 \mathrm{E}$ ) in the experiment presented in Figure $2 \mathrm{C}$ shows that by adding fresh pyruvate, the rates of reactions catalyzed by both enzymes are increased to their maximum again and that is why L-homoserine concentration starts to increase after the addition of pyruvate. Having a high rate of pyruvate consumption, $r_{3}$ is of crucial importance to avoid equilibrium limitations of the transaminase reaction toward the $\mathrm{L}$ homoserine formation. As pyruvate concentration drops, the rate of its consumption also declines, which will eventually have a negative effect on the rate of L-homoserine production.

In the next step, experiments with the simultaneous addition of both L-alanine and pyruvate were carried out, analogously to the experiments performed with CFE. ${ }^{18}$ An experiment with an addition of both substrates after $6.5 \mathrm{~h}$ is presented in Figure 3A. This strategy worked well with both CFE and LWCB, reaching ca. $47.6 \mathrm{~g} \mathrm{~L}^{-1}(400 \mathrm{mM})$ of product after $24 \mathrm{~h}$. 4Hydroxy-2-oxobutanoate accumulated at a concentration of about $260 \mathrm{mM}$ after $12 \mathrm{~h}$. This experiment was repeated (Figure 3B) at a higher concentration of LWCB but did not have any effect, and similar results as in the first experiment (Figure 3A) were achieved. Extending the reaction time up to $48 \mathrm{~h}$ was detrimental for both L-homoserine and 4-hydroxy-2oxobutanoate. This was because L-homoserine and probably also 4-hydroxy-2-oxobutanoate were consumed by cell metabolism (Section S3, SI). It was demonstrated in our previous work with CFE that 4-hydroxy-2-oxobutanoate is slowly transformed. ${ }^{18}$

Considering that the same strategy can be applicable for LWCB and CFE, two additions of L-alanine and pyruvate were 


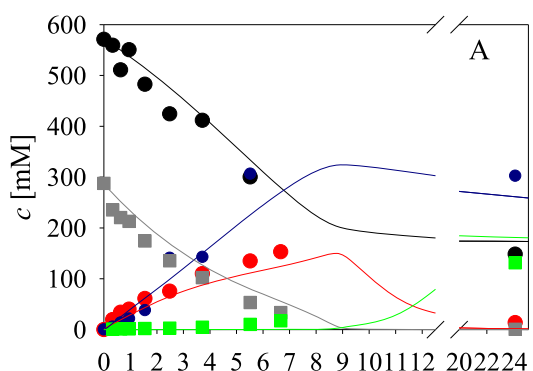

$t[\mathrm{~h}]$

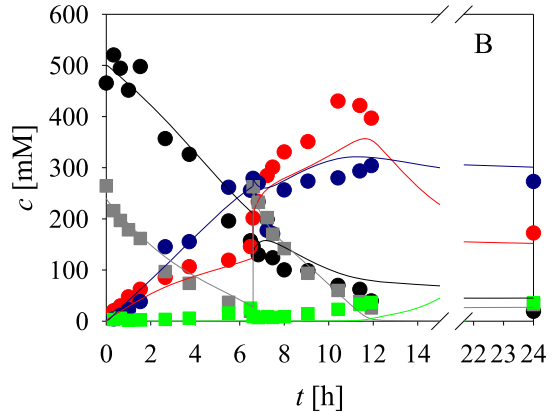

$t[\mathrm{~h}]$

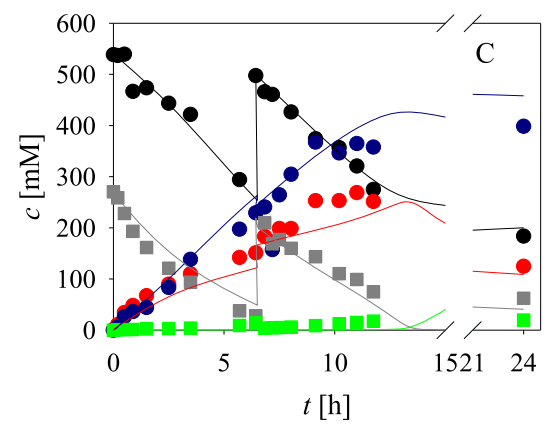

Figure 5. Simulations of the mathematical model for the experiments are presented in (A) Figures 1A, (B) 2C, and (C) 3A.
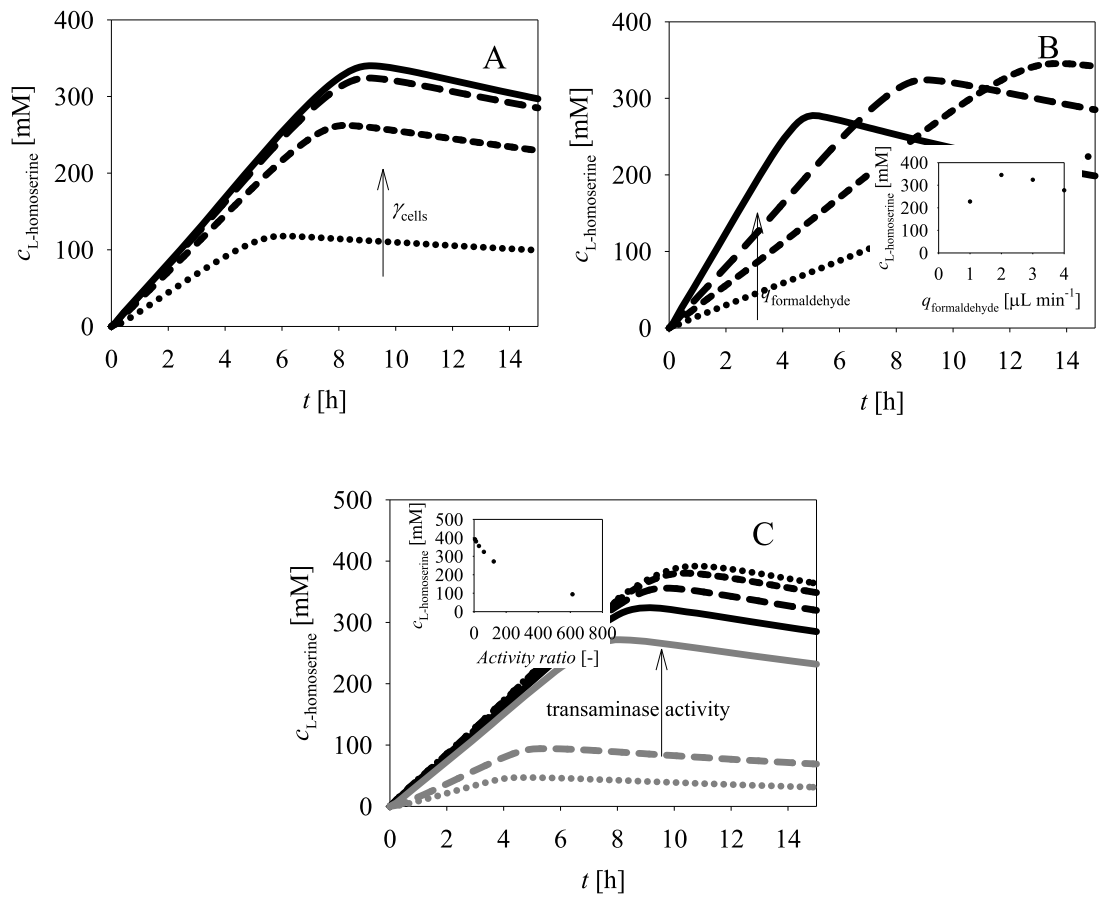

Figure 6. Influence of (A) biocatalyst concentration (legend: dotted line, $10 \mathrm{mg} \mathrm{mL}^{-1}$; short dash, $30 \mathrm{mg} \mathrm{mL}^{-1}$; long dash, $57 \mathrm{mg} \mathrm{mL}{ }^{-1}$; solid line, $75 \mathrm{mg} \mathrm{mL}^{-1}$ ) and (B) formaldehyde flow rate (legend: dotted line, $1 \mu \mathrm{L} \mathrm{min}^{-1}$; short dash, $2 \mu \mathrm{L} \mathrm{min}^{-1}$; long dash, $3 \mu \mathrm{L} \min ^{-1}$; solid line, $4 \mu \mathrm{L}$ $\mathrm{min}^{-1}$ ), and (C) enzyme expression level (legend: black dotted line, activity ratio 6.1; black short dash, activity ratio 12.3; black long dash, activity ratio 30.7; black solid line, activity ratio 61.3; gray solid line, activity ratio 122.7; gray long dash line, activity ratio 613.4; gray dotted line, activity ratio 1226.7) on the concentration of L-homoserine. Simulations were done at the initial conditions of the experiment presented in Figure 1A, unless otherwise stated.

envisaged to further increase the concentration of $\mathrm{L}$ homoserine. Under these conditions, L-homoserine reached a concentration of $76.3 \mathrm{~g} \mathrm{~L}^{-1}(640.8 \mathrm{mM})$ (Figure 4). Interestingly, this concentration was similar to that accomplished with purified enzymes and CFE $\left(80.1 \mathrm{~g} \mathrm{~L}^{-1}\right)^{18,42}$ and it is an excellent result for this complex reaction system. This is a remarkable achievement since using $\mathrm{LWCB}$, the probability of side reactions with substrates that are central to cell metabolism was high. The impact of pyruvate and L-alanine addition on the reaction rates is even more significant than that of pyruvate addition. This can be observed in Figure 4B where the maximum rates of pyruvate consumption $\left(r_{3}\right)$, as well as Lhomoserine formation $\left(r_{1}\right)$, are significantly higher than presented in Figure 2D,E. 
An overview of the effectiveness of pyruvate recycling in LWCB (Table 2) shows that a minimum of $\sim 80 \%$ of pyruvate is spent and that the amount of produced L-homoserine per consumed pyruvate differs for each experiment. Experiments presented in Figures 1A, 3, and 4 could be compared with those carried out with $\mathrm{CFE},{ }^{18}$ considering similar experimental conditions. The amount of produced L-homoserine per consumed pyruvate varied significantly for CFE depending on the activity ratio of $\mathrm{YfaU} 013$ and transaminase from 1.18 up to 2.04 mmolL-homoserine $\mathrm{mmol}_{\text {pyruvate }}{ }^{-1}$, being the best at the lowest activity ratio. It is difficult to draw similar conclusions for LWCB as numbers follow a similar range from 1.09 up to $2.28 \mathrm{mmolL}$-homoserine $\mathrm{mmol}_{\text {pyruvate }}{ }^{-1}$ but the activity ratio of enzymes is constant. Under the best experimental conditions for both CFE and LWCB (Figure 4), similar amount of pyruvate was spent, i.e., ca. $81 \%$ with LWCB and $82 \%$ with CFE. Interestingly, the amount of produced L-homoserine per consumed pyruvate is better for the LWCB (2.28 mmolL-homoserine $\left.\mathrm{mmol}_{\text {pyruvate }}{ }^{-1}\right)$ than for CFE (1.54 mmoll-homoserine $\mathrm{mmol}_{\text {pyruvate }}{ }^{-1}$ ).

3.5. Modeling. After the experimental investigation of the system, the mathematical model (Tables $1 \mathrm{a}$ and $1 \mathrm{~b}$ ) was used to simulate the data. Like in the CFE system, it was found that the model predicts the trends of the experimental data. However, it was necessary to re-estimate the maximum reaction rates (i.e., $\left.V_{\mathrm{m} 1}, V_{\mathrm{m} 2}, V_{\mathrm{m} 3}, V_{\mathrm{m} 4}\right),{ }^{18}$ considering the substrate channeling ${ }^{55-60}$ that occurs even easier within the cells. The re-estimated parameters are designated in SI (Tables $\mathrm{S} 1$ and S2). A significant difference can be observed for $V_{\mathrm{m} 3}$, similar to the previous work, ${ }^{18}$ while other differences are in the range of 2 -fold increase or decrease. The kinetic parameters for the biodegradation of pyruvate were also re-estimated $\left(V_{\mathrm{m} 7}\right.$, $\left.K_{\mathrm{m} 7 \text {,pyruvate }}\right)$. Apart from the substrate channeling, an additional reason for the differences in the estimated kinetic parameters could be in the undetected side reactions that may occur within the cells. These reactions, if present, could not be assessed but could affect the reactions by forming side products that may inhibit or change the reaction rates and, thus, the process metrics. Three experiments (Figures 1A, 2C, and $3 \mathrm{~A}$ ) were simulated (Figure 5) showing that the mathematical model describes the data well, which is also supported by the statistical output (Section S4, Table S4, SI). There is a deviation in the model regarding 4-hydroxy-2oxobutanoate formation, but the data shows the same trend as compared with CFE (second part of the experiments presented in Figure 5B,C). As far as the data presented in Figure $5 B, C$ is concerned, it should be noted that in the second part of the experiment, after the addition of pyruvate and L-alanine, the operational stability decay of the first order was added to the model for both enzymes (eq 11) to describe the data better. The estimated values of the operational stability decay rate constants of the first order, $k_{\mathrm{d}}$, for transaminase and aldolase were $7.07 \times 10^{-5}$ and $1.66 \times 10^{-3} \mathrm{~min}^{-1}$, respectively. This shows that the enzymes within the cells slowly lose their activity, which is less significant for the transaminase with a half-life time of $163 \mathrm{~h}$ and more important for the aldolase (half-life time $7 \mathrm{~h}$ ).

Several simulations (Figure 6) were run to evaluate some of the effects of biocatalyst concentration, formaldehyde flow rate feed, and level of enzyme expression, i.e., activities of individual enzymes on the final L-homoserine concentration. According to that (Figure 6A), the concentration of the LWCB chosen (57-75 $\mathrm{mg} \mathrm{mL}^{-1}$, Figures $\left.1-4\right)$ was optimal to achieve the maximum concentration of L-homoserine. Then, the influence of formaldehyde flow rate on the concentration of $\mathrm{L}$ homoserine was studied (Figure 6B). It appears that the optimal was at $2 \mu \mathrm{L} \mathrm{min}^{-1}$. Under these conditions, a higher Lhomoserine concentration (inset of Figure $6 \mathrm{~B}$ ) than at $3 \mu \mathrm{L}$ $\mathrm{min}^{-1}$ was obtained, but the reaction rate was slower. Therefore, the use of a higher formaldehyde flow rate (experiments in Figures 1-4) is well justified.

The final simulation (Figure 6C) shows how the enzyme expression level affects the concentration of L-homoserine. According to the measurements of the enzyme activities within the cells, it was calculated that the enzyme activity ratio was approximately 61.3 , meaning that the activity of $\mathrm{YfaU} 013$ is 61.3-fold higher than the activity of TA 039 (Figure 6C). According to the simulations, if transaminase expression is increased further within the cells in comparison to the ratio applied in this work, the maximum concentration of $\mathrm{L}$ homoserine could be increased from 324 up to $391 \mathrm{mM}$. This was simulated to show how mathematical modeling and simulations can facilitate optimization, reduce experimental effort, and theoretically investigate if the maximum product concentration could be further improved. However, this was not verified experimentally considering that it is not easy to adjust the activity ratio of enzymes within a single cell to an exact specific value. Cells with different enzyme activity ratios were prepared and initially tested (data not shown) but were discarded as no good. The influence of the activity ratio within the cells on the final concentration of L-homoserine (inset of Figure 6C) shows that the selected activity ratio was close to the optimum value, and further improvement can be expected by increasing the transaminase expression level. Additional simulation presented in Figure S7 (SI) shows a high level of similarity between the CFE ${ }^{18}$ and LWCB systems, indicating that the CFE results serve as an excellent groundwork for biocatalyst optimization. Hence, mathematical models can be used for process optimization (Figure 6A,B), as well as for biocatalyst optimization (Figure 6C). Without simulations, the experiments needed to reach the same conclusions would have been time- and resource-consuming, i.e., producing biocatalysts and the corresponding assays. By applying the mathematical models, different scenarios can be tested in silico, speeding up biocatalyst and process development, and industrial implementation.

Additional simulations (data not shown) were done to find the major reason why pyruvate recycling was not more successful, and it appears that the main problem is the strong inhibition of the transaminase activity by formaldehyde and the relatively high $K_{\mathrm{m} 3 \text {,pyruvate }}$ (Table $\mathrm{S} 2$ ), meaning that pyruvate concentration needs to be relatively high to achieve the maximum reaction rate in the aldol addition. The improvement of transaminase with respect to formaldehyde inhibition would enable a process with higher formaldehyde concentrations, which is currently a limiting factor. As far as the Michaelis constant for pyruvate with $\mathrm{YfaU}$ is concerned, lowering of its value would enable a more efficient pyruvate consumption by obtaining high values of reaction rate $r_{3}$ even at low pyruvate concentration. Accordingly, this would lead to faster L-homoserine formation $\left(r_{1}\right)$.

3.6. Volume Productivity and Biocatalyst Yield. The volume $\left(Q_{V}\right)$, biocatalyst productivity $\left(Y_{\text {biocatalyst }}\right)$, and, product concentration $\left(\gamma_{\mathrm{L}}\right.$-homoserine) are important metrics for bioprocess implementation and were calculated for all of the experiments (Table 3). As expected, $Q_{v}$ was the highest for the 
shortest experiment (Figure 1A and Table 3). However, in this case, the concentration of product was not satisfactory. Thus, a compromise must be taken when more than one goal function is optimized, such as in this case.

Similar values of product concentration and $Q_{\mathrm{v}}$ were observed for both experiments (Figure 3), but $Y_{\text {biocatalyst }}$ differs because of the different concentrations of biocatalysts that were employed. In the best experiment, a high $Q_{\mathrm{v}}$ of $2.6 \mathrm{~g} \mathrm{~L}^{-1}$ $\mathrm{h}^{-1}$ and the highest concentration of product at $76.3 \mathrm{~g} \mathrm{~L}^{-1}$ were accomplished. These numbers are comparable to CFE that gave a $Q_{V}$ of $3.2 \mathrm{~g} \mathrm{~L}^{-1} \mathrm{~h}^{-1}$ and a product concentration of $80.1 \mathrm{~g} \mathrm{~L}^{-1}$. A $Y_{\text {biocatalyst }}$ of 1 gL-homoserine $\mathrm{g}_{\text {cells }}{ }^{-1}$ should still be increased according to the literature, ${ }^{61}$ together with the product yield calculated according to L-alanine, which is $65.2 \%$. The problem of the lower product yield is related to downstream processing procedures, which were not in the scope of this work. The literature suggests the use of chromatographic methods for the isolation of product. ${ }^{62}$ Using the engineered microorganism E. coli W3110 in a fedbatch fermentation, three different publications reported a ca. 2-fold lower L-homoserine concentration $\left(39.54,{ }^{35} 35.8,{ }^{37}\right.$ and $\left.37.57 \mathrm{~g} \mathrm{~L}^{-13838}\right)$ in a fed-batch fermentation after $40 \mathrm{~h}$ with $\mathrm{L}$ homoserine yield on a glucose of ca. $0.29-0.35 \mathrm{~g} \mathrm{~g}^{-1}$. With a constructed Corynebacterium glutamicum strain, $\mathrm{Li}$ and coauthors $^{36}$ reported $8.8 \mathrm{~g} \mathrm{~L}^{-1}(73.5 \mathrm{mM})$ of L-homoserine after $48 \mathrm{~h}$. Thus, the metrics obtained using LWCB with coexpressed enzymes are superior to those obtained by the fermentation technology.

\section{CONCLUSIONS}

The synthesis of L-homoserine in the reaction system consisting of transaminase and aldolase within LWCB starting from pyruvate, formaldehyde, and L-alanine was studied. After a detailed kinetic investigation, it was shown that similar rules apply for CFE and LWCB and that the same mathematical model can be applied for process optimization. The optimal operational conditions were close to those with CFE. ${ }^{18}$ The important fact was the level of expression of individual enzymes within the cells, which was crucial for the process outcome. The general outcome of this study is the fact that the design of LWCB and the biocatalytic process can be optimized by working with free enzymes. The mathematical model can predict the occurrences in the reactor. LWCB and CFE showed comparable efficiencies, and side reactions were not detrimental to the process outcome. The process metrics accomplished were satisfactory, i.e., $76.3 \mathrm{~g} \mathrm{~L}^{-1}$ and $2.6 \mathrm{~g} \mathrm{~L}^{-1}$ $\mathrm{h}^{-1}$. Further work should be directed toward increasing the biocatalyst yield, as well as product yield currently at $65.2 \%$ to ease the downstream processing. LWCBs are of great interest for further research due to low biocatalyst cost, no need for coenzyme addition, and good enzyme stability. This type of custom-made biocatalyst has a breakthrough potential for numerous biocatalytic process applications.

\section{ASSOCIATED CONTENT}

\section{SI Supporting Information}

The Supporting Information is available free of charge at https://pubs.acs.org/doi/10.1021/acs.iecr.1c02343.

Supporting Information includes complete kinetic data, experimental and kinetic parameters, compound stability studies in the context of cell's activity, statistical output of the simulated experiments, the apparatus used in the

experiments, and the comparison of the LWCB and CFE with regard to the influence of the enzyme activity ratio on the final concentration of the product (PDF)

\section{AUTHOR INFORMATION}

\section{Corresponding Author}

Zvjezdana Findrik Blažević - Faculty of Chemical Engineering and Technology, University of Zagreb, HR10000 Zagreb, Croatia; 10 orcid.org/0000-0002-53128951; Phone: +385 14597 157; Email: zfindrik@fkit.hr; Fax: +38514597133

\section{Authors}

Morana Česnik Katulić - Faculty of Chemical Engineering and Technology, University of Zagreb, HR-10000 Zagreb, Croatia

Martina Sudar - Faculty of Chemical Engineering and Technology, University of Zagreb, HR-10000 Zagreb, Croatia

Karel Hernández - Biotransformation and Bioactive Molecules Group, Institute of Advanced Chemistry of Catalonia, IQAC-CSIC, 08034 Barcelona, Spain

Yuyin Qi - Prozomix Ltd., Northumberland NE49 9HA, United Kingdom

Simon J. Charnock - Prozomix Ltd., Northumberland NE49 9HA, United Kingdom

Đurdica Vasić-Rački - Faculty of Chemical Engineering and Technology, University of Zagreb, HR-10000 Zagreb, Croatia

Pere Clapés - Biotransformation and Bioactive Molecules Group, Institute of Advanced Chemistry of Catalonia, IQACCSIC, 08034 Barcelona, Spain; 아이.org/0000-0001$5541-4794$

Complete contact information is available at:

https://pubs.acs.org/10.1021/acs.iecr.1c02343

\section{Notes}

The authors declare no competing financial interest.

\section{ACKNOWLEDGMENTS}

This project has received funding from the European Union's Horizon 2020 Research and Innovation Program under Grant Agreement no. 635595 (CarbaZymes). This communication reflects only the beneficiary's view, and the European Commission is not responsible for any use that may be made of the information it contains. The authors gratefully acknowledge Prozomix Ltd. (United Kingdom) for providing the lyophilized whole cells. The authors also acknowledge the Ministerio de Ciencia e Innovación (MICIN), the Fondo Europeo de Desarrollo Regional (FEDER) (grant RTI2018094637-B-I00), and Programación Conjunta Internacional (PCI2018-092937), through the initiative ERA CoBioTech (Tralaminol)

\section{LIST OF SYMBOLS AND ABBREVIATIONS}

$c$

$k$

$K_{\mathrm{i}}$

$K_{\mathrm{m}}$

$r$

S.A.

$t$

$V_{\text {enz }}$

$V_{\mathrm{m}}$ molar concentration, $\mathrm{mM}$

kinetic constant of the first order, $\mathrm{min}^{-1}$ inhibition constant, $\mathrm{mM}$

Michaelis constant, $\mathrm{mM}$ reaction rate, $\mathrm{mM} \mathrm{min}^{-1}$ specific activity, $\mathrm{U} \mathrm{mg}^{-1}$ reaction time, $\mathrm{min}$ enzyme volume, $\mathrm{mL}$ maximum reaction rate, $\mathrm{U} \mathrm{mg}^{-1}$ 
$V_{\mathrm{r}} \quad$ reactor volume, $\mathrm{mL}$

$q \quad$ volume flow rate, $\mu \mathrm{L} \mathrm{min}^{-1}$

$\gamma \quad$ mass concentration, $\mathrm{mg} \mathrm{mL}^{-1}$

$\mathrm{BnONH}_{2} \cdot \mathrm{HCl} O$-benzylhydroxylamine hydrochloride

HPLC high-performance liquid chromatography

PLP pyridoxal phosphate

TA 039 transaminase 039

YfaU 013 aldolase YfaU 013

\section{REFERENCES}

(1) Lima-Ramos, J.; Tufvesson, P.; Woodley, J. M. Application of environmental and economic metrics to guide the development of biocatalytic processes. Green Process. Synth. 2014, 3, 195-213.

(2) Wohlgemuth, R. Biocatalysis - key to sustainable industrial chemistry. Curr. Opin. Biotechnol. 2010, 21, 713-724.

(3) Sheldon, R. A.; Woodley, J. M. Role of biocatalysis in sustainable chemistry. Chem. Rev. 2018, 118, 801-838.

(4) Woodley, J. M. New frontiers in biocatalysis for sustainable synthesis. Curr. Opin. Green Sustainable Chem. 2020, 21, 22-26.

(5) Wu, S.; Snajdrova, R.; Moore, J. C.; Baldenius, K.; Bornscheuer, U. T. Biocatalysis: Enzymatic synthesis for industrial applications. Angew. Chem., Int. Ed. 2021, 60, 88-119.

(6) Tufvesson, P.; Lima-Ramos, J.; Haque, N. A.; Gernaey, K. V.; Woodley, J. M. Advances in the process development of biocatalytic processes. Org. Process Res. Dev. 2013, 17, 1233-1238.

(7) Yuan, W. C.; Lei, C. W.; Zhao, J. Q.; Wang, Z. H.; You, Y. Organocatalytic asymmetric cyclopropanation of 3-acylcoumarins with 3-halooxindoles: Access to spirooxindole-cyclopropa $[c]$ coumarin compounds. J. Org. Chem. 2021, 86, 2534-2544.

(8) Hauer, B. Embracing nature's catalysts: A viewpoint on the future of biocatalysis. ACS Catal. 2020, 10, 8418-8427.

(9) Hogan, M. C.; Woodley, J. M. Modelling of two enzyme reactions in a linked cofactor recycle system for chiral lactone synthesis. Chem. Eng. Sci. 2000, 55, 2001-2008.

(10) Braun, M.; Link, H.; Liu, L.; Schmid, R. D.; Weuster-Botz, D. Biocatalytic process optimization based on mechanistic modeling of cholic acid oxidation with cofactor regeneration. Biotechnol. Bioeng. 2011, 108, 1307-1317.

(11) Findrik, Z.; Vasić-Rački, Đ.; Lutz, S.; Daussmann, T.; Wandrey, C. Kinetic modeling of acetophenone reduction catalyzed by alcohol dehydrogenase from Thermoanaerobacter sp. Biotechnol. Lett. 2005, 27, 1087-1095.

(12) Findrik, Z.; Šimunović, I.; Vasić-Rački, Đ. Coenzyme regeneration catalyzed by $\mathrm{NADH}$ oxidase from Lactobacillus brevis in the reaction of L-amino acid oxidation. Biochem. Eng. J. 2008, 39, 319-327.

(13) Milker, S.; Fink, M. J.; Oberleitner, N.; Ressmann, A. K.; Bornscheuer, U. T.; Mihovilovic, M. D.; Rudroff, F. Kinetic modeling of an enzymatic redox cascade in vivo reveals bottlenecks caused by cofactors. Chem CatChem 2017, 9, 3420-3427.

(14) Zheng, Y.; Pan, Z.; Zhang, R.; Jenkins, B. M. Kinetic modeling for enzymatic hydrolysis of pretreated creeping wild ryegrass. Biotechnol. Bioeng. 2009, 102, 1558-1569.

(15) Scherkus, C.; Schmidt, S.; Bornscheuer, U. T.; Groger, H.; Kara, S.; Liese, A. Kinetic insights into $\varepsilon$-caprolactone synthesis: Improvement of an enzymatic cascade reaction. Biotechnol. Bioeng. 2017, 114, 1215-1221.

(16) Van Hecke, W.; Haltrich, D.; Frahm, B.; Brod, H.; Dewulf, J.; Van Langenhove, H.; Ludwig, R. A biocatalytic cascade reaction sensitive to the gas-liquid interface: Modeling and upscaling in a dynamic membrane aeration reactor. J. Mol. Catal. B: Enzym. 2011, 68, 154-161.

(17) Sudar, M.; Česnik, M.; Clapés, P.; Pohl, M.; Vasić-Rački, Đ.; Findrik Blažević, Z. A cascade reaction for the synthesis of Dfagomine precursor revisited: Kinetic insight and understanding of the system. New Biotechnol. 2021, 63, 19-28.

(18) Česnik, M.; Sudar, M.; Hernández, K.; Charnock, S.; VasićRački, Đ.; Clapés, P.; Findrik Blažević, Z. Cascade enzymatic synthesis of L-homoserine - mathematical modelling as a tool for process optimisation and design. React. Chem. Eng. 2020, 5, 747-759.

(19) Ruales-Salcedo, A. V.; Higuita, J. C.; Fontalvo, J.; Woodley, J. $M$. Design of enzymatic cascade processes for the production of lowpriced chemicals. Z. Naturforsch., C: J. Biosci. 2019, 74, 77-84.

(20) Sudar, M.; Findrik Blažević, Z. Enzyme Cascade Kinetic Modelling. In Enzyme Cascade Design and Modelling; Kara, S.; Rudroff, F., Eds.; Springer International Publishing: Switzerland, 2021; pp 91108 .

(21) France, S. P.; Hepworth, L. J.; Turner, N. J.; Flitsch, S. L. Constructing biocatalytic cascades: In vitro and in vivo approaches to de novo multi-enzyme pathways. ACS Catal. 2017, 7, 710-724.

(22) Rios-Solis, L.; Morris, P.; Grant, C.; Odeleye, A. O. O.; Hailes, H. C.; Ward, J. M.; Dalby, P. A.; Baganz, F.; Lye, G. J. Modelling and optimisation of the one-pot, multi-enzymatic synthesis of chiral amino-alcohols based on microscale kinetic parameter determination. Chem. Eng. Sci. 2015, 122, 360-372.

(23) Rudroff, F. Whole-cell based synthetic enzyme cascades-light and shadow of a promising technology. Curr. Opin. Chem. Biol. 2019, 49, 84-90.

(24) Winkler, C. K.; Schrittwieser, J. H.; Kroutil, W. Power of biocatalysis for organic synthesis. ACS Cent. Sci. 2021, 7, 55-71.

(25) Meffre, P. R. Syntheses of optically active 2-amino-4-oxobutyric acid and N,O-protected derivatives. Amino Acids 1999, 16, 251-272.

(26) Gomes, J.; Kumar, D. Production of L-methionine by submerged fermentation: A review. Enzyme Microb. Technol. 2005, 37, 3-18.

(27) Kang, M.; Tata, M.; Vakalapudi, S.; McLaughlin, P.; Mahajan, A.; Wickard, D.; Lorbert, S. J.; Brinkhaus, F.; Peterson, J. C. Enhanced L-Homoserine Production by Genetically Modified Escherichia coli Strains. WO2013134625A1, Sept 12, 2013.

(28) Hateley, M.; Kobler, C.; Weckbecker, C.; Haeussner, T.; Bilz, J.; Huthmacher, K. Method for Producing Methionine from Homoserine. WO2007085514A2, Aug 2, 2007.

(29) Lee, H. W.; Yang, Y. L.; Kim, S. Y.; Shin, Y. U.; Chang, J. S.; Um, H. W.; Goh, Y. H.; Jhon, S. H. Method for Producing Bio-Based Homoserine Lactone and Bio-Based Organic Acid from o-Acyl Homoserine Produced by Microorganisms. US20,140,296,466A1, Oct 2, 2014

(30) Sun, Y.; Ma, C.; Fu, H.; Mu, Y.; Xiu, Z. 1,3-Propanediol. In Bioprocessing of Renewable Resources to Commodity Bioproducts; Bisaria, V. S.; Kondo, A., Eds.; John Wiley \& Sons, Inc.: Hoboken, NJ, 2014; pp 289-326.

(31) Hong, K.-K.; Kim, J.; Yoon, J.; Park, H.-M.; Choi, S.; Song, G.; Lee, J.; Yang, Y.-L.; Shin, H.; Kim, J.; Cho, K.; Lee, J. O-succinyl-1homoserine-based $\mathrm{C} 4$-chemical production: Succinic acid, homoserine lactone, $\gamma$-butyrolactone, $\gamma$-butyrolactone derivatives, and 1,4butanediol. J. Ind. Microbiol. Biotechnol. 2014, 41, 1517-1524.

(32) Xu, J.; Saunders, C.; Green, P.; Velasquez, J. Microorganisms and Engineered Metabolic Pathways for Producing Acrylate and Other Products from Homoserine. EP2930244A1, Oct 14, 2015.

(33) Chen, Z.; Geng, F.; Zeng, A.-P. Protein design and engineering of a de novo pathway for microbial production of 1,3-propanediol from glucose. Biotechnol. J. 2015, 10, 284-289.

(34) Sanchez, S.; Rodriguez-Sanoja, R.; Ramos, A.; Demain, A. L. Our microbes not only produce antibiotics, they also overproduce amino acids. J. Antibiot. 2017, 82, 26-36.

(35) Li, H.; Wang, B.; Zhu, L.; Cheng, S.; Li, Y.; Zhang, L.; Ding, Z. Y.; Gu, Z. H.; Shi, G. Y. Metabolic engineering of Escherichia coli W3110 for L-homoserine production. Process Biochem. 2016, 51, $1973-1983$

(36) Li, N.; Xu, S.; Du, G.; Chen, J.; Zhou, J. Efficient production of L-homoserine in Corynebacterium glutamicum ATCC 13032 by redistribution of metabolic flux. Biochem. Eng. J. 2020, 161, No. 107665.

(37) Liu, M.; Lou, J.; Gu, J.; Lyu, X. M.; Wang, F. Q.; Wei, D. Z. Increasing L-homoserine production in Escherichia coli by engineering the central metabolic pathways. J. Biotechnol. 2020, 314-315, 1-7. 
(38) Liu, P.; Zhang, B.; Yao, Z. H.; Liu, Z. Q.; Zheng, Y. G. Multiplex design of the metabolic network for production of Lhomoserine in Escherichia coli. Appl. Environ. Microbiol. 2020, 86, No. e01477-20.

(39) Woodley, J. M. Reaction engineering for the industrial implementation of biocatalysis. Top. Catal. 2019, 62, 1202-1207.

(40) Trček, J.; Mira, N. P.; Jarboe, L. R. Adaptation and tolerance of bacteria against acetic acid. Appl. Microbiol. Biotechnol. 2015, 99, 6215-6229.

(41) Woodley, J. M. Advances in biological conversion technologies: New opportunities for reaction engineering. React. Chem. Eng. 2020, $5,632-640$.

(42) Hernández, K.; Bujons, J.; Joglar, J.; Charnock, S. J.; Domínguez de María, P.; Fessner, W. D.; Clapés, P. Combining aldolases and transaminases for the synthesis of 2-amino-4hydroxybutanoic acid. ACS Catal. 2017, 7, 1707-1711.

(43) Erb, T. J.; Jones, P. R.; Bar-Even, A. Synthetic metabolism: Metabolic engineering meets enzyme design. Curr. Opin. Chem. Biol. 2017, 37, 56-62.

(44) Kim, J.; Kershner, J. P.; Novikov, Y.; Shoemaker, R. K.; Copley, S. D. Three serendipitous pathways in E. coli can bypass a block in pyridoxal-5'-phosphate synthesis. Mol. Syst. Biol. 2010, 6, No. 436.

(45) Ghatge, M. S.; Contestabile, R.; di Salvo, M. L.; Desai, J. V.; Gandhi, A. K.; Camara, C. M.; Florio, R.; Gonzalez, I. N.; Parroni, A.; Schirch, V.; Safo, M. K. Pyridoxal 5'-phosphate is a slow tight binding inhibitor of E. coli pyridoxal kinase. PLoS One 2012, 7, No. e41680.

(46) di Salvo, M. L.; Nogues, I.; Parroni, A.; Tramonti, A.; Milano, T.; Pascarella, S.; Contestabile, R. On the mechanism of Escherichia coli pyridoxal kinase inhibition by pyridoxal and pyridoxal 5'phosphate. Biochim. Biophys. Acta, Proteins Proteomics 2015, 1854, $1160-1166$.

(47) https://www.genome.jp/kegg-bin/show_pathway?org_name= ecj\&mapno $=00250 \&$ show_description $=$ show (accessed June 01, 2021).

(48) Scientist Handbook; MicroMath: Salt Lake City, 1986-1995.

(49) Szymanski, W.; Postema, C. P.; Tarabiono, C.; Berthiol, F.; Campbell-Verduyn, L.; de Wildeman, S.; de Vries, J. G.; Feringa, B. L.; Janssen, D. B. Combining designer cells and click chemistry for a one-pot four-step preparation of enantiopure $\beta$-hydroxytriazoles. $A d v$. Synth. Catal. 2010, 352, 2111-2115.

(50) Chen, S.-Y.; Yang, C.-X.; Wu, J.-P.; Xu, G.; Yang, L.-R. Multienzymatic biosynthesis of chiral $\beta$-hydroxy nitriles through coexpression of oxidoreductase and halohydrin dehalogenase. Adv. Synth. Catal. 2013, 355, 3179-3190.

(51) Srinivasamurthy, V. S. T.; Bottcher, D.; Bornscheuer, U. T. A multi-enzyme cascade reaction for the production of 6-hydroxyhexanoic acid. Z. Naturforsch., C: J. Biosci. 2019, 74, 71-76.

(52) Israeli, E.; Giberman, E.; Kohn, A. Membrane malfunctions in freeze-dried Escherichia coli. Cryobiology 1974, 11, 473-477.

(53) Lin, B.; Tao, Y. Whole-cell biocatalysts by design. Microb. Cell Fact. 2017, 16, No. 106.

(54) Wachtmeister, J.; Rother, D. Recent advances in whole cell biocatalysis techniques bridging from investigative to industrial scale. Curr. Opin. Biotechnol. 2016, 42, 169-177.

(55) Teramura, M.; Tsukatani, Y.; Harada, J.; Hirose, M.; Tamiaki, $\mathrm{H}$. Stereoselective C3-substituent modification and substrate channeling by oxidoreductase $\mathrm{BchC}$ in bacteriochlorophyll a biosynthesis. FEBS Lett. 2019, 593, 799-809.

(56) Sanyal, N.; Arentson, B. W.; Luo, M.; Tanner, J. J.; Becker, D. F. First evidence for substrate channeling between proline catabolic enzymes: A validation of domain fusion analysis for predicting protein-protein interactions. J. Biol. Chem. 2015, 290, 2225-2234.

(57) Wheeldon, I.; Minteer, S. D.; Banta, S.; Barton, S. C.; Atanassov, P.; Sigman, M. Substrate channelling as an approach to cascade reactions. Nat. Chem. 2016, 8, 299-309.

(58) Hwang, E. T.; Lee, S. Multienzymatic cascade reactions via enzyme complex by immobilization. ACS Catal. 2019, 9, 4402-4425.

(59) Baker, P.; Hillis, C.; Carere, J.; Seah, S. Y. Protein-protein interactions and substrate channeling in orthologous and chimeric aldolase-dehydrogenase complexes. Biochemistry 2012, 51, 19421952.

(60) Pollmann, S.; Springer, A.; Rustgi, S.; von Wettstein, D.; Kang, C.; Reinbothe, C.; Reinbothe, S. Substrate channeling in oxylipin biosynthesis through a protein complex in the plastid envelope of Arabidopsis thaliana. J. Exp. Bot. 2019, 70, 1483-1495.

(61) Tufvesson, P.; Lima-Ramos, J.; Nordblad, M.; Woodley, J. M. Guidelines and cost analysis for catalyst production in biocatalytic processes. Org. Process Res. Dev. 2011, 15, 266-274.

(62) Karau, A. https://corporate.evonik.com/misc/epaper/ elements/30/elements-30-de.pdf (accessed July 25, 2021). 